\title{
Aplikasi Penentuan Jumlah Produksi di Farhan Konfeksi Kotamobagu dengan Menggunakan Fuzzy Tsukamoto
}

\author{
Michel Farrel Tomatala \\ STMIK Multicom Bolaang - Mongondow, Kotamobagu - Sulawesi Utara, Indonesia \\ correspondence e-mail: michel@stmikmulticom.ac.id
}

\begin{abstract}
Abstrak-Ketidakstabilan permintaan yang tinggi maupun rendah pada waktu tertentu serta permintaan secara mendadak mengakibatkan sulitnya menentukan jumlah produksi yang tepat. Ini mengakibatkan masalah penumpukan stok persediaan saat kelebihan jumlah produksi dan masalah sebaliknya yaitu kekurangan jumlah produksi sehingga tidak dapat memenuhi jumlah permintaan. Sebab itu dibutuhkan suatu aplikasi yang bisa dengan mudah digunakan untuk menentukan jumlah produksi yang tepat. Aplikasi ini menggunakan metode Fuzzy Tsukamoto dengan tiga tahap perhitungan jumlah produksi yaitu fuzzifikasi, inferensi dan defuzzifikasi. Pada tahap awal, variabel permintaan, persediaan dan produksi masing-masing dibagi menjadi tiga himpunan fuzzy. Variabel permintaan terdiri dari TURUN, TETAP dan NAIK, variabel persediaan terdiri dari SEDIKIT, SEDANG, dan BANYAK, serta variabel produksi terdiri dari BERKURANG, TETAP dan BERTAMBAH. Kombinasi semua himpunan fuzzy dibentuk menjadi sembilan rules fuzzy yang digunakan dalam tahap inferensi. Ditahap inferensi, dicari nilai keanggotaan anteseden ( $\alpha$ ) dan nilai jumlah produksi kira-kira (z) setiap rules-nya. Jumlah pakaian yang akan diproduksi (Z) dicari dengan metode defuzzifikasi rata-rata terpusat. Aplikasi ini memiliki tingkat kesalahan sebesar $0.324673 \%$ setelah diuji menggunakan 29 sampel dengan metode Mean Absolute Percentage Error (MAPE), sehingga disimpulkan bahwa aplikasi ini memiliki kinerja efektif tanpa mengurangi ketepatan perhitungan dan dapat digunakan untuk menentukan jumlah produksi dalam waktu singkat.
\end{abstract}

Kata Kunci-aplikasi; fuzzy; produksi; Tsukamoto;

Abstract-The instability of the high and law demand at particular time that sometimes happen in unexpected time caused the difficulties to determine the exact number of production. This caused the accumulation of the stocks at when there are extra productions and as reversed, it also caused the lack numbers of production then it caused the uncapability to fulfil the demand. Thus, it is necessary to create an application that can be used easily to determine exact numbers of production. This application uses Fuzzy Tsukamoto method by using three calculation phases; fuzzyfication, inference, and defuzzyfication. In initial stages, variables of demand, inventory, and production are divided into three fuzzy sets. Demand variable consists of DOWN, CONSTANT, and UP, the inventory variable consist of LITTLE, MEDIUM, and MANY, and production variable consists of DECREASED, CONSTANT, and INCREASED. The combination of all fuzzy sets have been formed into nine rules which is used at inference stage. At the inference stage, the value of anteseden $(\alpha)$ and the value of approximate production $(\mathrm{z})$ are determined. The quantity of clothes which are going to be produced $(Z)$ is searched by centralized mean defuzzyfication method. This application only has error rate as $0.324673 \%$ after being being tested for 29 samples by using Mean Absolute Percentage Error (MAPE) method, then it can be concluded that this application has effective performance by not reducing the calculation precision and can be used to determine the quantity of production briefly.

Keywords—application; fuzzy; production; Tsukamoto;

\section{PENDAhuluan}

Masalah terkait penentuan jumlah produksi biasanya dialami oleh i-rumah konfeksi dikarenakan penentuan jumlah produksi yang dilakukan hanya berdasarkan prediksi, ditambah lagi ketidakstabilan jumlah pesanan. Hal inilah yang mengakibatkan stok persediaan pakaian selalu bertambah dan akhirnya menumpuk atau mengalami kekurangan sehingga tidak dapat memenuhi jumlah permintaan.

Berdasarkan permasalahan yang ada di Farhan Konfeksi saat ini, dibutuhkan suatu aplikasi yang dapat dengan mudah digunakan untuk menentukan jumlah produksi pakaian yang tepat dengan sebuah metode untuk mengatasi masalah tersebut. Adapun metode yang digunakan untuk menentukan jumlah produksi, yaitu metode Fuzzy Tsukamoto [6]. Metode ini dipilih karena keunggulannya yaitu memiliki tingkat toleransi terhadap data yang tidak tepat dan penalaran fuzzy yang cukup mudah untuk dipahami [7]. Penelitian ini bertujuan untuk membangun sebuah aplikasi yang bisa dengan mudah digunakan untuk menentukan jumlah produksi pakaian di Farhan Konfeksi Kotamobagu menggunakan metode Fuzzy Tsukamoto. Dengan adanya sebuah aplikasi yang bisa dengan mudah digunakan untuk membantu Farhan 
Konfeksi dalam menentukan jumlah produksi pakaian yang ideal sehingga masalah penumpukan dan juga masalah kekurangan stok pakaian yang sering dialami oleh Farhan Konfeksi dapat diatasi. Adapun beberapa batasan masalah yang diuraikan dan diteliti dalam penelitian ini adalah sebagai berikut:

1. Jumlah produksi ditetukan berdasarkan jumlah persediaan dan permintaan.

2. Data yang digunakan sebagai berikut: persediaan (maksimum dan minimum), permintaan (maksimum dan minimum), produksi (maksimum dan minimum) pada satu periode tertentu, permintaan saat ini dan persediaan saat ini.

Penggunaan aplikasi ini dikhususkan untuk pihak rumah konfeksi yang bertanggung jawab untuk menentukan jumlah produksi dalam hal ini manager produksi Farhan Konfeksi.

\section{TINJAUAN PUSTAKA}

Fuzzy Inference System Dengan Metode Tsukamoto Sebagai Penunjang Keputusan Produksi (Studi Kasus: PT. Talkindo Selaksa Anugrah) merupakan salah satu judul penelitian yang terkait dengan penelitian ini. Dalam sistem penunjang keputusan ini ada tiga variabel yang dimodelkan, yaitu: permintaan, persediaan dan produksi. Masing-masing variabel terdiri dari dua himpunan fuzzy yaitu: TURUN dan NAIK untuk variabel permintaan, SEDIKIT dan BANYAK, untuk variabel persediaan serta BERKURANG dan BERTAMBAH untuk variabel produksi. Ada empat aturan fuzzy yang digunakan dalam tahap inferensi. Pada tahap inferensi, dicari nilai keanggotaan anteseden $(\alpha)$ dan nilai perkiraan jumlah produksi (z) dari setiap aturan. Jumlah barang yang akan diproduksi (Z) dicari dengan defuzzifikasi rata-rata terpusat [8]. Adapun pada penelitian ini, dengan menggunakan metode yang sama akan dibangun sebuah aplikasi untuk memudahkan penentuan jumlah produksi dengan menggunakan tiga variabel yang sama yaitu permintaan, persediaan dan produksi. Setiap variabel terdiri dari 3 himpunan yaitu TURUN, TETAP dan NAIK untuk variabel permintaan, SEDIKIT, SEDANG dan BANYAK untuk variabel persediaan serta BERKURANG, TETAP dan BERTAMBAH untuk variabel produksi sehingga terbentuk sembilan rules yang selanjutnya digunakan dalam tahap inferensi dimana secara teori [3] Menyatakan bahwa penambahan jumlah rules yang digunakan dalam inferensi akan berpengaruh pada keakuratan hasil perhitungan jumlah produksi. Pada tahap inferensi, dicari nilai keanggotaan anteseden $(\alpha)$ dan nilai perkiraan jumlah produksi $(z)$ dari setiap aturan. Jumlah barang yang akan diproduksi (Z) dicari dengan metode defuzzifikasi rata-rata terpusat [5]. Diharapkan dengan adanya aplikasi ini bisa memberikan hasil berupa jumlah produksi pakaian yang ideal untuk mengatasi masalah penumpukan dan kekurangan stok pakaian yang dialami oleh Farhan Konfeksi.

\section{METODE PENELITIAN}

\section{Pengumpulan Data}

Pengumpulan data diperoleh secara langsung dari objek penelitian dan referensi-referensi yang telah diperoleh [10]. Cara-cara yang digunakan untuk mengumpulkan data adalah sebagai berikut :

\section{a) Studi Lapangan}

Datang langsung di tempat penelitian dan melakukan observasi dan wawancara.

\section{b) Studi Literatur}

Pengumpulan data yang berkaitan dengan penelitian. Pengumpulan data yang dilakukan bersumber dari materi-materi yang berkaitan dengan penelitian yang dilakukan.

\section{Identifikasi Masalah}

Seringnya kejadian penumpukan stok persediaan akibat penentuan jumlah produksi yang belum tepat di perusahaan Farhan Konfeksi Kotamobagu.

\section{Pengelolahan Data dengan Metode Fuzzy Tsukamoto}

Setiap konsekuen pada aturan yang berbentuk If-Then harus direpresentasikan dengan suatu himpunan fuzzy dengan fungsi keanggotaan yang monoton [9]. Sebagai hasilnya output hasil inferensi dari tiap-tiap aturan diberikan secara tegas (crisp) berdasarkan $\alpha$-predikat (fire strength) [4]. Hasil akhirnya diperoleh dengan menggunakan rata-rata terbobot.

\section{a) Domain}

Domain Himpunan Fuzzy adalah keseluruhan nilai yang diijinkan dalam semesta pembicaraan dan boleh dioperasikan dalam suatu himpunan Fuzzy. Seperti halnya semesta pembicaraan, domain merupakan bilangan real yang senantiasa naik (bertambah) secara monoton dari kiri ke kanan. Nilai domain dapat berupa bilangan positif maupun bilangan negative [1]. Contoh domain himpunan Fuzzy: Muda $=[0,45]$. Penelitian ini dirancang untuk menentukan jumlah produksi pakaian di Farhan Konfeksi dengan jmenggunakan data yang diperoleh dari Farhan Konfeksi yaitu data produksi pada bulan Juli 2017 yang dapat dilihat pada Tabel 1 . 
Tabel 1. Produksi pakaian Farhan Konfeksi periode bulan Juli 2017

\begin{tabular}{|c|c|c|c|}
\hline Tanggal & Permintaan & Persediaan & Produksi \\
\hline $1-07-2017$ & 200 & 30 & 180 \\
\hline $2-07-2017$ & 150 & 22 & 130 \\
\hline 3-07-2017 & 230 & 30 & 200 \\
\hline 4-07-2017 & 220 & 30 & 200 \\
\hline $5-07-2017$ & 180 & 25 & 160 \\
\hline 6-07-2017 & 225 & 28 & 200 \\
\hline $7-07-2017$ & 210 & 28 & 190 \\
\hline $8-07-2017$ & 150 & 20 & 130 \\
\hline 9-07-2017 & 170 & 20 & 150 \\
\hline $10-07-2017$ & 120 & 25 & 100 \\
\hline $11-07-2017$ & 200 & 28 & 180 \\
\hline $12-07-2017$ & 130 & 20 & 110 \\
\hline $13-07-2017$ & 210 & 30 & 180 \\
\hline 14-07-2017 & 215 & 30 & 170 \\
\hline $15-07-2017$ & 110 & 25 & 90 \\
\hline $16-07-2017$ & 270 & 30 & 240 \\
\hline $17-07-2017$ & 210 & 30 & 170 \\
\hline 18-07-2017 & 190 & 18 & 170 \\
\hline 19-07-2017 & 185 & 20 & 185 \\
\hline $20-07-2017$ & 210 & 20 & 190 \\
\hline $21-07-2017$ & 190 & 20 & 170 \\
\hline $22-07-2017$ & 150 & 15 & 145 \\
\hline $23-07-2017$ & 230 & 25 & 210 \\
\hline $24-07-2017$ & 140 & 20 & 125 \\
\hline $25-07-2017$ & 170 & 20 & 160 \\
\hline $26-07-2017$ & 195 & 25 & 170 \\
\hline $27-07-2017$ & 200 & 25 & 180 \\
\hline $28-07-2017$ & 180 & 12 & 170 \\
\hline $29-07-2017$ & 240 & 30 & 210 \\
\hline $30-07-2017$ & 180 & 12 & 170 \\
\hline $31-07-2017$ & 140 & 20 & 125 \\
\hline $1-08-2017$ & 170 & 25 & \\
\hline
\end{tabular}

Data permintaan merupakan data yang terkumpul dari hari sebelumnya sampai pada hari tersebut. Data pada tanggal 31 Juli 2017 merupakan data permintaan yang masuk sejak tanggal 30 Juli 2017 setelah produksi pada tanggal tersebut (30 Juli 2017). Data permintaan yang masuk tanggal 30 sampai tanggal 31 Juli 2017 diakumulasikan sebagai data permintaan saat ini. Secara ringkas dapat dilihat pada Gambar 1.

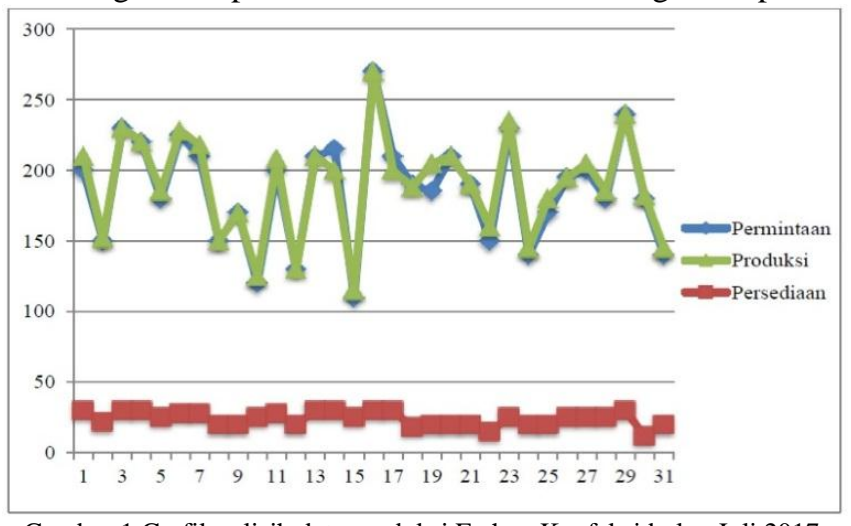

Gambar 1 Grafik selisih data produksi Farhan Konfeksi bulan Juli 2017.

Grafik pada Gambar 1 bertujuan untuk memperlihatkan objek visualisasi dari tabel produksi Farhan Konfeksi bulan Juli 2017. Dari data grafik ini dihasilkan data maksimum dan minimum yang akan digunakan untuk menghitung jumlah produksi dengan metode Fuzzy Tsukamoto, seperti pada tabel 2.

\begin{tabular}{|c|c|c|}
\hline Data & Jumlah & Satuan \\
\hline Permintaan Maximum $\left(\mathrm{X}_{\max }\right)$ & 270 & \multirow{6}{*}{ Lembar/Hari } \\
\hline Permintaan Minimum $\left(\mathrm{X}_{\min }\right)$ & 110 & \\
\hline Persediaan Maximum $\left(\mathrm{X}_{\max }\right)$ & 30 & \\
\hline Persediaan Minimum $\left(\mathrm{X}_{\min }\right)$ & 12 & \\
\hline Produksi Maximum $\left(\mathrm{X}_{\max }\right)$ & 240 & \\
\hline Produksi Minimum $\left(\mathrm{X}_{\min }\right)$ & 90 & \\
\hline
\end{tabular}




\section{b) Fuzzifikasi}

Nilai keanggotaan himpunan permintaan dan persediaan dicari menggunakan fungsi keanggotaan himpunan Fuzzy dengan memperhatikan nilai maksimum dan nilai minimum data 1 periode tertentu dari tiap variabel. Variabel 1 periode terakhir yaitu; variabel permintaan, variabel persediaan dan variabel produksi.

1) Variabel Permintaan

Variabel Permintaan terdiri atas 3 himpunan Fuzzy, yaitu : TURUN, TETAP dan NAIK.

a) Fungsi keanggotaan himpunan Fuzzy TURUN variabel permintaan

Fungsi keanggotaan himpunan Fuzzy TURUN dari himpunan Fuzzy permintaan menurut [1] sesuai dengan data pada tabel 2 dimana permintaan $\max =270$ dan permintaan minimum $=110$ adalah:

$$
\begin{aligned}
& \mu \text { Permintaan TURUN }[\mathrm{X}]=\left\{\begin{array}{cl}
1, & \mathrm{X} \leq 110 \\
\frac{270-X}{270-110}, & 110 \leq \mathrm{X} \leq 270 \\
0, & \mathrm{X} \geq 270
\end{array}\right. \\
& \mu \text { Permintaan TURUN }[\mathrm{X}]=\left\{\begin{array}{cl}
1 & \mathrm{X} \leq X_{\min } \\
\frac{X_{\max }-X}{X_{\max }-X_{\min },}, & X_{\min } \leq \mathrm{X} \leq X_{\max } \\
0 & , \mathrm{X} \geq X_{\max }
\end{array}\right.
\end{aligned}
$$

b) Fungsi keanggotaan himpunan Fuzzy TETAP variabel permintaan

Fungsi keanggotaan himpunan Fuzzy TETAP dari himpunan Fuzzy permintaan menurut [1] sesuai dengan data pada tabel 2 dimana permintaan $\max =270$ dan permintaan minimum $=110$ adalah:

$$
\begin{aligned}
& \mu \text { Permintaan TETAP }[\mathrm{X}]= \begin{cases}1,, \mathrm{X} \leq X_{\min } \\
\frac{X-X_{\min }}{X_{t}-X_{\min }}, X_{\min } \leq \mathrm{X} \leq X_{t} \\
\frac{X_{\max }-X}{X_{\max }-X_{t}}, & X_{t} \leq \mathrm{X} \leq X_{\max } \\
0 & , \mathrm{X} \leq X_{\min } \cup X \geq X_{\max }\end{cases} \\
& \mu \text { Permintaan TETAP }[X]=\left\{\begin{array}{cl}
\frac{X-110,}{190-110,} & 100 \leq X \leq 190 \\
\frac{190-X}{270-190,}, & 190 \leq X \leq 270 \\
0 & X \leq 110 \cup X \geq 270
\end{array}\right.
\end{aligned}
$$

c) Fungsi keanggotaan himpunan Fuzzy NAIK variabel permintaan

Fungsi keanggotaan himpunan Fuzzy NAIK dari himpunan Fuzzy permintaan menurut [1] sesuai dengan data pada tabel 2 dimana permintaan $\max =270$ dan permintaan minimum $=110$ adalah:

$$
\begin{aligned}
& \mu \text { Permintaan NAIK }[\mathrm{X}]=\left\{\begin{array}{cl}
0, & \mathrm{X} \leq X_{\min } \\
\frac{X-X_{\min }}{X_{\max }-X_{\min }}, & X_{\min } \leq \mathrm{X} \leq X_{\max } \\
1, & \mathrm{X} \geq X_{\max }
\end{array}\right. \\
& \mu \text { Permintaan NAIK }[\mathrm{X}]=\left\{\begin{array}{cl}
0, & \mathrm{X} \leq 110 \\
\frac{X-110}{270-110}, & 110 \leq \mathrm{X} \leq 270 \\
1, & \mathrm{X} \geq 270
\end{array}\right. \\
& \text { Ket: } \mathrm{Xt}=\frac{X_{\max }+X_{\min }}{2} \\
& \quad=\frac{270+110}{2}=190
\end{aligned}
$$

Fungsi keanggotaan himpunan Fuzzy TURUN, TETAP, dan NAIK dari variabel permintaan menurut [1] direpresentasikan pada Gambar 2.

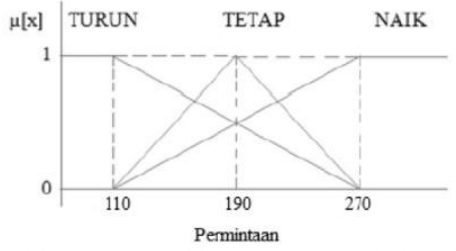

Gambar 2. Fungsi keanggotaan himpunan fuzzy dari variabel permintaan

Gambar 2. merupakan representasi grafik variabel permintaan yang terdiri dari 3 himpunan yaitu TURUN, TETAP, dan NAIK. Himpunan TURUN direpresentasikan dengan garis linear turun, himpunan TETAP direpresentasikan dengan kurva segitiga dan himpunan NAIK direpresentasikan dengan garis 
linear naik dengan nilai permintaan minimum $=110$, nilai permintaan tetap $=190$, dan nilai permintaan maximum $=270$. Sesuai dengan data yang diperoleh pada Tabel 1, diketahui bahwa jumlah permintaan saat ini adalah 170 sehingga nilai keanggotaan tiap himpunan pada variabel permintaan menurut [1] dapat dicari dengan cara :

$$
\begin{aligned}
\mu_{\text {permintaan TURUN[170] }} & =\frac{X_{\max }-X}{X_{\max }-X_{\min }} \\
& =\frac{270-170}{270-110} \\
& =\frac{100}{160} \\
& =0,625 \\
\mu_{\text {permintaan TETAP[170] }} & =\frac{X-X_{\min }}{X_{t}-X_{\min }} \\
& =\frac{170-110}{190-110} \\
& =\frac{60}{80} \\
& =0,75 \\
\mu_{\text {permintaan NAIK[170] }} & =\frac{X-X_{\min }}{X_{\max }-X_{\min }} \\
& =\frac{170-110}{270-110} \\
& =\frac{60}{160} \\
& =0,375
\end{aligned}
$$

2) Variabel Persediaan

Variabel Persediaan terdiri 3 himpunan fuzzy, yaitu SEDIKIT, SEDANG dan BANYAK.

a) Fungsi keanggotaan himpunan fuzzy SEDIKIT variabel persediaan

Fungsi keanggotaan himpunan fuzzy SEDIKIT dari himpunan Fuzzy persediaan menurut [1] sesuai dengan tabel 2 dimana persediaan $\max =30$ dan persediaan minimum $=12$ adalah:

$$
\begin{aligned}
& \mu_{\text {persediaan }} \text { SEDIKIT }[\mathrm{y}]=\left\{\begin{array}{cc}
\frac{1}{y_{\max }-y}, & \mathrm{y} \leq y_{\min } \\
y_{\max }-y_{\min }, & y_{\min } \leq \mathrm{y} \leq y_{\max }
\end{array}\right. \\
& \mu_{\text {persediaan }} \text { SEDIKIT }[\mathrm{y}]=\left\{\begin{array}{cc}
1, & \mathrm{y} \geq y_{\max } \\
\frac{30-y}{30-12}, & \mathrm{y} \leq 12 \\
0, & 12 \leq \mathrm{y} \leq 30
\end{array}\right.
\end{aligned}
$$

b) Fungsi keanggotaan himpunan fuzzy SEDANG variabel persediaan

Fungsi keanggotaan himpunan fuzzy SEDANG dari himpunan Fuzzy persediaan menurut [1] sesuai dengan tabel 2 dimana persediaan $\max =30$ dan persediaan minimum $=12$ adalah:

$$
\begin{aligned}
& \mu_{\text {persediaan }} \operatorname{SEDANG}[\mathrm{y}]= \begin{cases}1 & , \mathrm{y} \leq y_{\min } \\
\frac{y-y_{\min }}{y_{t}-y_{\min }}, & y_{\min } \leq \mathrm{y} \leq y_{t} \\
\frac{y_{\max }-y}{y_{\max }-y_{t}}, & y_{t} \leq \mathrm{y} \leq y_{\max } \\
0 & , \mathrm{y} \leq y_{\min } \cup y \geq y_{\max }\end{cases} \\
& \mu_{\text {persediaan }} \text { SEDANG }[\mathrm{y}]= \begin{cases}\frac{1}{21-12}, & 12 \leq \mathrm{y} \leq 21 \\
\frac{21-y}{30-12}, & 21 \leq \mathrm{y} \leq 30 \\
0 & \mathrm{y} \leq 12 \cup \mathrm{y} \geq 30\end{cases}
\end{aligned}
$$

c) Fungsi keanggotaan himpunan fuzzy BANYAK variabel persediaan

Fungsi keanggotaan himpunan fuzzy BANYAK dari himpunan Fuzzy persediaan menurut [1] sesuai dengan tabel 2 dimana persediaan $\max =30$ dan persediaan minimum $=12$ adalah:

$$
\mu_{\text {persediaan }} \text { BANYAK }[\mathrm{y}]=\left\{\begin{array}{cl}
0, & \mathrm{y} \leq y_{\min } \\
\frac{y-y_{\min }}{y_{\max }-y_{\min }}, & y_{\min } \leq \mathrm{y} \leq y_{\max } \\
1, & \mathrm{y} \geq y_{\max }
\end{array}\right.
$$




$$
\begin{aligned}
& \mu_{\text {persediaan }} \text { BANYAK }[\mathrm{y}]= \begin{cases}0, & \mathrm{y} \leq 12 \\
\frac{y-12}{30-12}, & 12 \leq \mathrm{y} \leq 30 \\
1, & \mathrm{y} \geq 30\end{cases} \\
& \text { Ket: yt }=\frac{y_{\max }+y_{\min }}{2}=\frac{30+12}{2}=21
\end{aligned}
$$

Fungsi keanggotaan himpunan Fuzzy SEDIKIT, SEDANG, dan BANYAK dari variabel persediaan menurut [1] direpresentasikan pada Gambar 3.

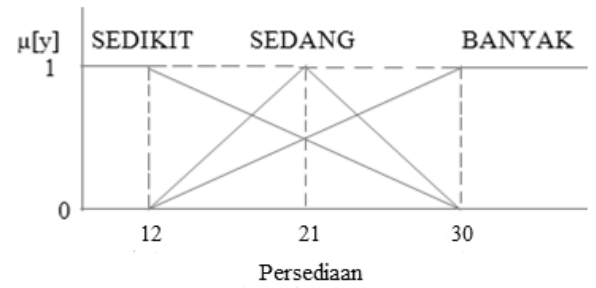

Gambar 3. Fungsi keanggotaan himpunan fuzzy dari variabel persediaan

Gambar 3 merupakan representasi grafik variabel persediaan yang teridiri dari 3 himpunan yaitu SEDIKIT, SEDANG, BANYAK. Himpunan SEDIKIT direpresentasikan dengan garis linear turun, himpunan SEDANG direpresentasikan dengan kurva segitiga dan himpunan BANYAK direpresentasikan dengan garis linear naik dengan nilai persediaan SEDIKIT $=12$, nilai persediaan SEDANG $=21$ dan nilai persediaan BANYAK $=30$. Sesuai dengan data yang diperoleh pada tabel 1 jumlah persediaan saat ini adalah 25, sehingga nilai keanggotaan tiap himpunan pada variabel persediaan dapat dicari dengan cara :

$$
\begin{aligned}
\mu_{\text {persediaan SEDIKIT[25] }} & =\frac{y_{\max }-y}{y_{\max }-y_{\min }} \\
& =\frac{30-25}{30-12} \\
& =\frac{5}{18} \\
& =0,277 \\
\mu_{\text {persediaan SEDANG[25] }} & =\frac{y_{\max }-y}{y_{\max }-y_{t}} \\
& =\frac{30-25}{30-21} \\
& =\frac{5}{9} \\
& =0,56 \\
\mu_{\text {persediaan BANYAK[25] }} & =\frac{y-y_{\min }}{y_{\max }-y_{\min }} \\
& =\frac{25-12}{30-12} \\
& =\frac{13}{18} \\
& =0,72 \\
&
\end{aligned}
$$

3) Variabel Produksi

Variabel Produksi terdiri 3 himpunan fuzzy, yaitu BERKURANG, TETAP dan BERTAMBAH.

a) Fungsi keanggotaan himpunan fuzzy BERKURANG variabel produksi

Fungsi keanggotaan himpunan fuzzy BERKURANG dari himpunan Fuzzy produksi menurut [1] sesuai dengan tabel 2 dimana produksi $\max =240$ dan produksi minimum $=90$ adalah:

$$
\begin{aligned}
& \mu \text { Produksi BERKURANG[Z] }=\left\{\begin{array}{cl}
1 & , \mathrm{Z} \leq Z_{\min } \\
\frac{Z_{\max }-Z}{Z_{\max }-Z_{\min }}, & Z_{\min } \leq \mathrm{Z} \leq Z_{\max } \\
0 & \mathrm{Z} \geq Z_{\max }
\end{array}\right. \\
& \mu \text { Produksi BERKURANG }[\mathrm{Z}]=\left\{\begin{array}{cl}
1 & \mathrm{Z} \leq 90 \\
\frac{240-Z}{240-90,}, & 90 \leq \mathrm{Z} \leq 240 \\
0, & \mathrm{Z} \geq 240
\end{array}\right.
\end{aligned}
$$


b) Fungsi keanggotaan himpunan fuzzy TETAP variabel produksi

Fungsi keanggotaan himpunan fuzzy TETAP dari himpunan Fuzzy produksi menurut [1] sesuai dengan tabel 2 dimana produksi $\max =240$ dan produksi minimum $=90$ adalah:

$$
\begin{aligned}
& \mu \text { Produksi TETAP }[\mathrm{Z}]= \begin{cases}1,, \mathrm{Z} \leq Z_{\min } \\
\frac{Z-Z_{\min }}{Z_{t}-Z_{\min }}, Z_{\min } \leq \mathrm{Z} \leq Z_{t} \\
\frac{Z_{\max }-Z}{Z_{\max }-Z_{t}}, & Z_{t} \leq \mathrm{Z} \leq Z_{\max } \\
0 & , \mathrm{Z} \leq Z_{\min } \cup \mathrm{Z} \geq Z_{\max }\end{cases} \\
& \mu \text { Produksi TETAP }[\mathrm{Z}]=\left\{\begin{array}{cl}
\frac{1}{\frac{Z-90}{165-90},} & \mathrm{Z} \leq 90 \\
\frac{240-Z}{240-165}, & 165 \leq \mathrm{Z} \leq 240 \\
0 & \mathrm{Z} \leq 90 \cup \mathrm{Z} \geq 240
\end{array}\right.
\end{aligned}
$$

c) Fungsi keanggotaan himpunan fuzzy BERTAMBAH variabel produksi

Fungsi keanggotaan himpunan fuzzy BERTAMBAH dari himpunan Fuzzy produksi menurut [1] sesuai dengan tabel 2 dimana produksi $\max =240$ dan produksi minimum $=90$ adalah:

$$
\begin{aligned}
& \mu \text { Produksi BERTAMBAH }[\mathrm{Z}]=\left\{\begin{array}{cl}
0, & \mathrm{Z} \leq Z_{\min } \\
\frac{Z-Z_{\min }}{Z_{\max }-Z_{\min }}, & Z_{\min } \leq \mathrm{Z} \leq Z_{\max } \\
1, & \mathrm{Z} \geq Z_{\max }
\end{array}\right. \\
& \mu \text { Produksi BERTAMBAH }[\mathrm{Z}]=\left\{\begin{array}{cl}
0, & \mathrm{Z} \leq 90 \\
\frac{Z-90}{240-90}, & 90 \leq \mathrm{Z} \leq 240 \\
1, & \mathrm{Z} \geq 240
\end{array}\right. \\
& \text { Ket: } \mathrm{Zt}=\frac{Z_{\max }+Z_{\min }}{2}=\frac{240+90}{2}=165
\end{aligned}
$$

Fungsi keanggotaan himpunan Fuzzy BERKURANG, TETAP, dan BERTAMBAH dari variabel produksi menurut [1] direpresentasikan pada Gambar 4.

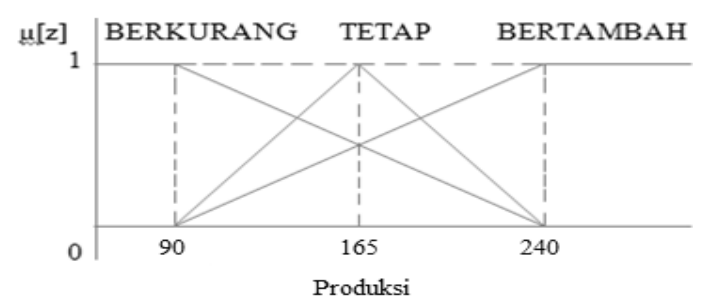

Gambar 4. Fungsi keanggotaan himpunan fuzzy dari variabel produksi

Gambar 4 merupakan representasi grafik variabel produksi yang teridiri dari 3 himpunan yaitu BERKURANG, TETAP, BERTAMBAH. Himpunan BERKURANG direpresentasikan dengan garis linear turun, himpunan TETAP direpresentasikan dengan kurva segitiga dan himpunan BERTAMBAH direpresentasikan dengan garis linear naik dengan nilai produksi BERKURANG $=90$, nilai produksi TETAP $=165$ dan nilai produksi BERTAMBAH $=240$. Kemudian masuk pada tahap inferensi dengan menggunakan sistem inferensi Fuzzy seperti pada gambar 5.

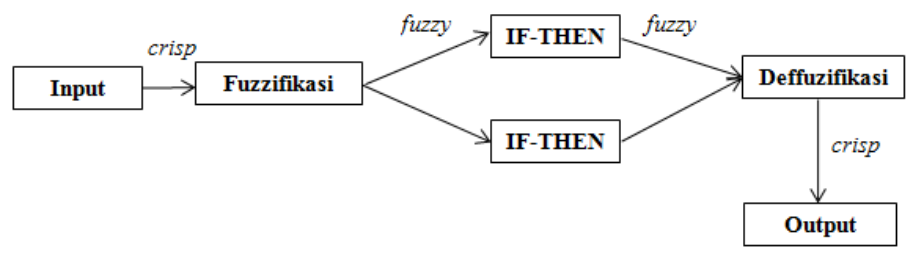

Gambar 5. Diagram blok sistem inferensi Fuzzy

Pada gambar 5 tahap pertama dimulai dengan melakukan input data yang bersifat crisp (tegas) ke setiap rules yang ada sehingga memperoleh nilai anteseden $(\alpha)$ dan jumlah perkiraan produksi $(\mathrm{z})$ untuk setiap rules kemudian nilai-nilai tersebut dihitung menggunakan metode defuzzifikasi rata-rata terpusat untuk menghasilkan nilai output Z (jumlah produksi barang). Dalam proses inferensi menurut [1] ada beberapa persamaan yang digunakan yaitu : 
I. Jika produksi BERKURANG, maka menurut persamaan (7) diperoleh persamaan :

$\frac{Z_{\max }-Z_{n}}{Z_{\max }-Z_{\min }}=\alpha_{n}$

Sehingga dari persamaan (10) diperoleh persamaan berikut :

$Z_{n}=Z_{\max }-\alpha_{n}\left(Z_{\max }-Z_{\min }\right)$

II. Jika Produksi TETAP, maka :
$Z_{n}=Z_{t}$
(12)

III. Jika Produksi BERTAMBAH, maka menurut fungsi keanggotaan himpunan produksi BERTAMBAH pada persamaan 9 diperoleh persamaan :

$\frac{Z_{n}-Z_{\min }}{Z_{\max }-Z_{\min }}=\alpha_{n}$

Sehingga dari persamaan (13) diperoleh persamaan berikut :

$Z_{n}=\alpha_{n}\left(Z_{\max }-Z_{\min }\right)+Z_{\min }$

c) Rules

Perancangan rules berdasarkan [2] yaitu 9 rules yang digunakan adalah sebagai berikut :

[R1] IF Permintaan TURUN And Persediaan BANYAK THEN Produksi BERKURANG

Nilai keanggotaan anteseden untuk aturan Fuzzy [R1] yang dinotasikan dengan $\alpha 1$ diperoleh dengan rumus sebagai berikut:

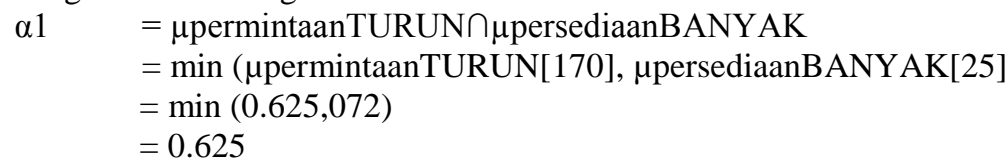

Kondisi produksi BERKURANG, maka untuk menghitung nilai z1 digunakan persamaan 11:

$$
\begin{aligned}
\mathrm{z} 1 & =\mathrm{Z}_{\max }-\alpha 1\left(\mathrm{Z}_{\max }-\mathrm{Z}_{\min }\right) \\
& =240-0.625(240-90) \\
& =240-0.625(150) \\
& =240-93.75 \\
& =146.25
\end{aligned}
$$

[R2] IF Permintaan TURUN And Persediaan SEDANG THEN Produksi BERKURANG

Nilai keanggotaan anteseden untuk aturan Fuzzy [R2] yang dinotasikan dengan $\alpha 2$ diperoleh dengan rumus sebagai berikut:

$$
\begin{aligned}
\alpha 2 & =\mu \text { permintaanTURUN } \cap \mu \text { persediaanSEDANG } \\
& =\min (\mu \text { permintaanTURUN[170], } \mu \text { persediaanSEDANG[25] } \\
& =\min (0.625,0.56) \\
& =0.56
\end{aligned}
$$

Kondisi produksi BERKURANG, maka untuk menghitung nilai z2 digunakan persamaan 11:

$\mathrm{z} 2=\mathrm{Z}_{\max }-\alpha 2\left(\mathrm{Z}_{\max }-\mathrm{Z}_{\min }\right)$

$=240-0.56(240-90)$

$=240-0.56(150)$

$=240-84$

$=156$

[R3] IF Permintaan TURUN And Persediaan SEDANG THEN Produksi BERKURANG

Nilai keanggotaan anteseden untuk aturan Fuzzy [R3] yang dinotasikan dengan $\alpha 3$ diperoleh dengan rumus sebagai berikut:

$\alpha 3=\mu$ permintaanTURUN $\cap \mu$ persediaanSEDIKIT

$=\min (\mu$ permintaanTURUN[170], $\mu$ persediaanSEDIKIT[25]

$=\min (0.625,0.277)$

$$
=0.277
$$

Kondisi produksi BERKURANG, maka untuk menghitung nilai z3 digunakan persamaan 11:

$$
\begin{aligned}
\mathrm{z} 3 & =Z_{\max }-\alpha 3\left(Z_{\max }-Z_{\min }\right) \\
& =240-0.277(240-90) \\
& =240-0.277(150) \\
& =240-41.55 \\
& =198.45
\end{aligned}
$$

[R4] IF Permintaan TETAP And Persediaan BANYAK THEN Produksi BERKURANG

Nilai keanggotaan anteseden untuk aturan Fuzzy [R4] yang dinotasikan dengan $\alpha 4$ diperoleh dengan rumus sebagai berikut: 
$\alpha 3=\mu$ permintaanTETAP $\cap \mu$ persediaanBANYAK

$=\min (\mu$ permintaanTETAP[170], $\mu$ persediaanBANYAK[25]

$=\min (0.75,0.72)$

$=0.72$

Kondisi produksi BERKURANG, maka untuk menghitung nilai z4 digunakan persamaan 11:

$\mathrm{z} 4=\mathrm{Z}_{\max }-43\left(\mathrm{Z}_{\max }-\mathrm{Z}_{\min }\right)$

$=240-0.72(240-90)$

$=240-0.72(150)$

$=240-108$

$=132$

[R5] IF Permintaan TETAP And Persediaan SEDANG THEN Produksi TETAP

Nilai keanggotaan anteseden untuk aturan Fuzzy [R5] yang dinotasikan dengan $\alpha 5$ diperoleh dengan rumus sebagai berikut:

$\alpha 5=\mu$ permintaanTETAP $\cap \mu$ persediaanSEDANG

$=\min (\mu$ permintaanTETAP $[170], \mu$ persediaanSEDANG[25]

$=\min (0.75,0.56)$

$$
=0.56
$$

Kondisi produksi TETAP, maka untuk menghitung nilai z5 digunakan persamaan 12: Jadi z5 = 165

[R6] IF Permintaan TETAP And Persediaan SEDIKIT THEN Produksi BERTAMBAH

Nilai keanggotaan anteseden untuk aturan Fuzzy [R6] yang dinotasikan dengan $\alpha 6$ diperoleh dengan rumus sebagai berikut:

$\alpha 6=\mu$ permintaanTETAP $\cap \mu$ persediaanSEDIKIT

$=\min (\mu$ permintaanTETAP[170], $\mu$ persediaanSEDIKIT[25]

$=\min (0.75,0.277)$

$=0.277$

Kondisi produksi BERTAMBAH, maka untuk menghitung nilai z6 digunakan persamaan 14:

z6 $=\alpha 6\left(\mathrm{Z}_{\max }-\mathrm{Z}_{\min }\right)+\mathrm{Z}_{\text {min }}$

$=0.277(240-90)+90$

$=0.277(150)+90$

$=41.55+90=131.55$

[R7] IF Permintaan NAIK And Persediaan BANYAK THEN Produksi Barang BERTAMBAH

Nilai keanggotaan anteseden untuk aturan Fuzzy [R7] yang dinotasikan dengan $\alpha 7$ diperoleh dengan rumus sebagai berikut:

$\alpha 7=\mu$ permintaanNAIK $\cap \mu$ persediaanBANYAK

$=\min (\mu$ permintaanTETAP[170], $\mu$ persediaanBANYAK[25]

$=\min (0.375,0.625)$

$=0.375$

Kondisi produksi BERTAMBAH, maka untuk menghitung nilai z7 digunakan persamaan 14:

$$
\begin{aligned}
\mathrm{z} 7 & =\alpha 7\left(\mathrm{Z}_{\max }-\mathrm{Z}_{\min }\right)+\mathrm{Z}_{\min } \\
& =0.375(240-90)+90 \\
& =0.375(150)+90 \\
& =56.25+90 \\
& =146.25
\end{aligned}
$$

[R8] IF Permintaan NAIK And Persediaan SEDANG THEN Produksi BERTAMBAH

Nilai keanggotaan anteseden untuk aturan Fuzzy [R8] yang dinotasikan dengan $\alpha 8$ diperoleh dengan rumus sebagai berikut:

$\alpha 8=\mu$ permintaanNAIK $\cap \mu$ persediaanSEDANG

$=\min (\mu$ permintaanNAIK[170], $\mu$ persediaanSEDANG[25]

$=\min (0.375,0.56)$

$$
=0.375
$$

Kondisi produksi BERTAMBAH, maka untuk menghitung nilai z7 digunakan persamaan 14:

$\mathrm{z} 8=\alpha 8\left(\mathrm{Z}_{\max }-\mathrm{Z}_{\min }\right)+\mathrm{Z}_{\min }$

$=0.375(240-90)+90$

$=0.375(150)+90$

$=56.25+90$

$=146.25$

[R9] IF Permintaan NAIK And Persediaan SEDIKIT THEN Produksi BERTAMBAH

Aplikasi Penentuan Jumlah Produksi di Farhan Konfeksi Kotamobagu dengan Menggunakan Fuzzy Tsukamoto (Michel Farrel Tomatala) 
Nilai keanggotaan anteseden untuk aturan Fuzzy [R9] yang dinotasikan dengan $\alpha 9$ diperoleh dengan rumus sebagai berikut:

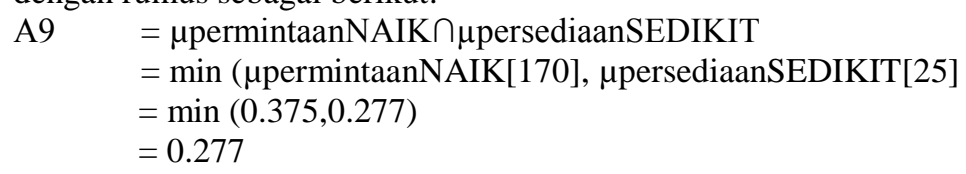

Kondisi produksi BERTAMBAH, maka untuk menghitung nilai z9 digunakan persamaan 14:

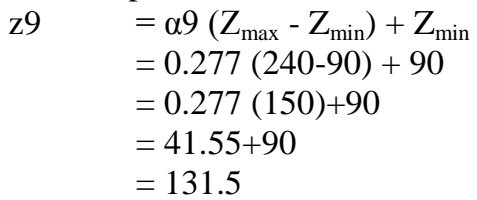

d) Proses Defuzzifikasi

Proses Defuzzifikasi ini digunakan untuk menentukan output crisp Z (hasil akhir hitungan jumlah produksi). Menurut [8] untuk memperoleh hasil akhir $\mathrm{Z}$ digunakan metode defuzzifikasi rata-rata terpusat yaitu dengan cara:

$$
\begin{aligned}
& Z=\frac{\alpha 1 * Z 1+\alpha 2 * Z 2+\cdots+\alpha n * Z n}{\alpha 1+\alpha 2+\cdots+\alpha n} \\
& Z=\frac{\alpha 1 * Z 1+\alpha 2 * Z 2+\alpha 3 * Z 3+\alpha 4 * Z 4+\alpha 5 * Z 5+\alpha 6 * Z 6+\alpha 7 * Z 7+\alpha 8 * Z 8+\alpha 9 * Z 9}{\alpha 1+\alpha 2+\alpha 3+\alpha 4+\alpha 5+\alpha 6+\alpha 7+\alpha 8+\alpha 9} \\
& Z=\frac{0.625 * 146.25+0.56 * 156+0.277 * 198.45+0.72 * 132+0.56 * 165+0.277 * 131.55}{+0.375 * 146.25+0.375 * 146.25+0.277 * 131.55} \\
& Z=\frac{603.71}{4.046}=149.211
\end{aligned}
$$

Jadi jumlah pakaian yang seharusnya diproduksi oleh Farhan Konfeksi pada bulan selanjutnya untuk hari pertama yaitu pada tanggal 1 Agustus 2017 berdasarkan perhitungan menggunakan metode Fuzzy Tsukamoto adalah 149 lembar.

e) Perancangan Perangkat Lunak (Aplikasi)
a. Communication
b. Planning
c. Modeling
d. Construction

\begin{tabular}{|c|c|c|c|c|c|c|c|}
\hline \multirow[t]{2}{*}{$\mathrm{N}$} & \multirow[t]{2}{*}{ Tanggal } & \multirow[t]{2}{*}{ Permintaan } & \multirow[t]{2}{*}{ Persediaan } & \multirow{2}{*}{$\begin{array}{c}\text { Hasil } \\
\text { Perhitungan } \\
\text { Manual }\end{array}$} & \multirow{2}{*}{$\begin{array}{c}\text { Hasil } \\
\text { Perhitungan } \\
\text { Aplikasi }\end{array}$} & \multicolumn{2}{|c|}{$\begin{array}{c}\text { Jumlah Produksi } \\
\text { (Hasil Pembulatan) }\end{array}$} \\
\hline & & & & & & Manual & Aplikasi \\
\hline 1 & 11-07-17 & 200 & 28 & 155.112 & 155.110 & 155 & 155 \\
\hline 2 & $16-07-17$ & 270 & 30 & 200 & 200 & 200 & 200 \\
\hline 3 & $17-07-17$ & 210 & 30 & 159.642 & 159.642 & 160 & 160 \\
\hline 4 & $18-07-17$ & 190 & 18 & 202.5 & 202.5 & 203 & 203 \\
\hline 5 & 19-07-17 & 185 & 20 & 178.744 & 178.593 & 179 & 179 \\
\hline 6 & $20-07-17$ & 210 & 20 & 181.996 & 181.987 & 182 & 182 \\
\hline 7 & $21-07-17$ & 190 & 20 & 179.991 & 180 & 180 & 180 \\
\hline 8 & $22-07-17$ & 150 & 15 & 140 & 140 & 140 & 140 \\
\hline 9 & $23-07-17$ & 230 & 25 & 176.901 & 176.944 & 177 & 177 \\
\hline 10 & $24-07-17$ & 140 & 20 & 149.930 & 149.886 & 150 & 150 \\
\hline 11 & $25-07-17$ & 170 & 20 & 162.325 & 162.115 & 162 & 162 \\
\hline 12 & $26-07-17$ & 195 & 25 & 161.238 & 161.394 & 161 & 161 \\
\hline 13 & $27-07-17$ & 200 & 25 & 163.655 & 163.557 & 164 & 164 \\
\hline 14 & $28-07-17$ & 180 & 25 & 154.815 & 154.903 & 155 & 155 \\
\hline 15 & $29-07-17$ & 240 & 30 & 204.124 & 204.204 & 204 & 204 \\
\hline 16 & $30-07-17$ & 180 & 12 & 186.115 & 186.25 & 186 & 186 \\
\hline 17 & $31-07-17$ & 140 & 20 & 146.242 & 146.320 & 146 & 146 \\
\hline 18 & $1-08-17$ & 170 & 25 & 149.211 & 149.228 & 149 & 149 \\
\hline
\end{tabular}
e. Deployment

IV. HASIL DAN DISKUSI

Hasil untuk perbandingan jumlah produksi secara manual dan hasil perhitungan menggunakan aplikasi akan disajikan pada tabel 3 . 


\begin{tabular}{cccccccc}
\hline $\mathrm{N}$ & Tanggal & Permintaan & Persediaan & $\begin{array}{c}\text { Hasil } \\
\text { Perhitungan } \\
\text { Manual }\end{array}$ & $\begin{array}{c}\text { Hasil } \\
\text { Perhitungan } \\
\text { Aplikasi }\end{array}$ & \multicolumn{2}{c}{$\begin{array}{c}\text { Jumlah Produksi } \\
\text { (Hasil Pembulatan) } \\
\text { Manual }\end{array}$} \\
\hline 19 & $2-08-17$ & 110 & 30 & 90 & 90 & 90 & 90 \\
\hline 20 & $3-08-17$ & 190 & 28 & 144.854 & 144.807 & 145 & 145 \\
\hline 21 & $4-08-17$ & 270 & 26 & 178.372 & 178.461 & 178 & 178 \\
\hline 22 & $5-08-17$ & 265 & 24 & 181.120 & 181.218 & 181 & 181 \\
\hline 23 & $6-08-17$ & 260 & 22 & 191.505 & 191.549 & 191 & 191 \\
\hline 24 & $7-08-17$ & 255 & 20 & 190.493 & 190.585 & 190 & 191 \\
\hline 25 & $8-08-17$ & 240 & 18 & 180.885 & 180.900 & 181 & 181 \\
\hline 26 & $9-08-17$ & 220 & 16 & 180.535 & 180.513 & 181 & 181 \\
\hline 27 & $10-08-17$ & 200 & 14 & 187.639 & 187.634 & 188 & 188 \\
\hline 28 & $11-08-17$ & 190 & 20 & 166.739 & 166.744 & 167 & 167 \\
\hline 29 & $12-08-17$ & 180 & 22 & 159.454 & 159.350 & 159 & 159 \\
\hline 30 & $13-08-17$ & 170 & 24 & 150.585 & 150.576 & 151 & 151 \\
\hline 31 & $14-08-17$ & 160 & 26 & 149.460 & 149.486 & 149 & 149 \\
\hline
\end{tabular}

Tabel 3 menyajikan perbandingan jumlah produksi yang diperoleh dari hasil perhitungan secara manual dan hasil perhitungan menggunakan aplikasi dari hasil penelitian ini. Bisa dilihat bahwa ada 31 data yang digunakan sebagai sampel untuk pengujian aplikasi penentuan jumlah produksi ini, dan dari ke 31 data tersebut hanya ada satu data yang berbeda hasil perhitungannya namun hal itu disebabkan oleh pembulatan nominal angkanya saja.

Tabel 4 Perbandingan jumlah produksi Farhan Konfeksi dan hasil perhitungan aplikasi

\begin{tabular}{|c|c|c|c|c|c|c|}
\hline $\mathrm{N}$ & Tanggal & Permintaan & Persediaan & $\begin{array}{c}\text { Jumlah Produksi } \\
\text { oleh Farhan } \\
\text { Konfeksi }\end{array}$ & $\begin{array}{c}\text { Jumlah Produksi } \\
\text { Berdasarkan Hasil } \\
\text { Perhitungan Aplikasi }\end{array}$ & Ket \\
\hline 1 & $1-07-2017$ & 200 & 30 & 180 & \multirow{2}{*}{\multicolumn{2}{|c|}{ Digunakan sebagai database }} \\
\hline 2 & $2-07-2017$ & 150 & 22 & 130 & & \\
\hline 3 & 3-07-2017 & 230 & 30 & 200 & 180 & 20 \\
\hline 4 & 4-07-2017 & 220 & 30 & 190 & 190 & 0 \\
\hline 5 & $5-07-2017$ & 180 & 25 & 160 & 163 & -3 \\
\hline 6 & 6-07-2017 & 225 & 28 & 200 & 172 & 28 \\
\hline 7 & $7-07-2017$ & 210 & 28 & 190 & 170 & 20 \\
\hline 8 & $8-07-2017$ & 150 & 20 & 130 & 130 & 0 \\
\hline 9 & 9-07-2017 & 170 & 20 & 150 & 153 & -3 \\
\hline 10 & $10-07-2017$ & 120 & 25 & 100 & 148 & -48 \\
\hline 11 & $11-07-2017$ & 200 & 28 & 180 & 155 & 25 \\
\hline 12 & $12-07-2017$ & 130 & 20 & 110 & 110 & 0 \\
\hline 13 & 13-07-2017 & 210 & 30 & 180 & 177 & 3 \\
\hline 14 & $14-07-2017$ & 215 & 30 & 170 & 183 & -13 \\
\hline 15 & $15-07-2017$ & 110 & 25 & 90 & 125 & -35 \\
\hline 16 & $16-07-2017$ & 270 & 30 & 240 & 200 & 40 \\
\hline 17 & $17-07-2017$ & 210 & 30 & 240 & 200 & 40 \\
\hline 18 & $18-07-2017$ & 190 & 18 & 170 & 160 & 10 \\
\hline 19 & 19-07-2017 & 185 & 20 & 185 & 179 & 6 \\
\hline 20 & $20-07-2017$ & 210 & 20 & 190 & 182 & 8 \\
\hline 21 & $21-07-2017$ & 190 & 20 & 170 & 180 & -10 \\
\hline 22 & $22-07-2017$ & 150 & 15 & 145 & 140 & 5 \\
\hline 23 & $23-07-2017$ & 230 & 25 & 210 & 177 & 33 \\
\hline 24 & $24-07-2017$ & 140 & 20 & 125 & 150 & -25 \\
\hline 25 & $25-07-2017$ & 170 & 20 & 160 & 162 & -2 \\
\hline 26 & $26-07-2017$ & 195 & 25 & 170 & 161 & 9 \\
\hline 27 & $27-07-2017$ & 200 & 25 & 180 & 164 & 16 \\
\hline 28 & $28-07-2017$ & 180 & 25 & 160 & 155 & 5 \\
\hline 29 & 29-07-2017 & 240 & 30 & 210 & 204 & 6 \\
\hline 30 & $30-07-2017$ & 180 & 12 & 170 & 186 & -16 \\
\hline 31 & $31-07-2017$ & 140 & 20 & 125 & 146 & -21 \\
\hline
\end{tabular}

Berdasarkan Tabel 4 terdapat selisih antara antara jumlah produksi yang ditentukan oleh Farhan Konfeksi dan jumlah produksi yang ditentukan berdasarkan hasil perhitungan jumlah produksi menggunakan aplikasi. Selisih tersebutlah yang bisa menyebabkan terjadinya masalah penumpukan stok persediaan maupun masalah sebaliknya yaitu terjadinya kekurangan stok di Farhan Konfeksi Kotamobagu sehingga tidak dapat memenuhi jumlah permintaan yang ada. Untuk lebih jelasnya, selisih tersebut ditampilkan dalam bentuk grafik line pada Gambar 6. 


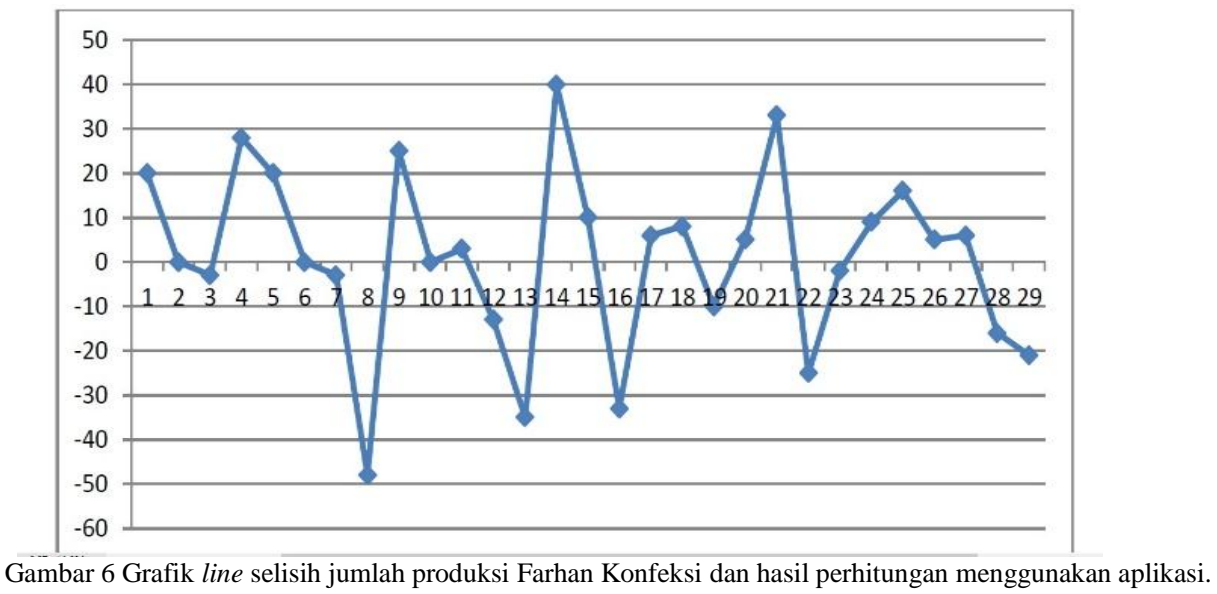

Grafik line ini bertujuan untuk memperlihatkan objek visualisasi dari selisih antara jumlah produksi yang ditentukan oleh Farhan Konfeksi dan jumlah produksi yang ditentukan berdasarkan hasil perhitungan jumlah produksi menggunakan aplikasi pada Tabel 4.

Untuk menguji tingkat kesalahan dari aplikasi penentuan jumlah produksi menggunakan metode Fuzzy Tsukamato ini digunakan metode Mean Absolute Percentage Error (MAPE). Adapun rumus

$$
M A P E=\frac{\sum \frac{X_{1}-X_{2}}{X_{1}} \times 100 \%}{n}
$$

MAPE adalah sebagai berikut:

Keterangan :

1. $\mathrm{X} 1=$ Jumlah produksi actual (aktual)

2. $\mathrm{X} 2$ = Jumlah produksi forecast (peramalan jumlah produksi menggunakan metode Fuzzy Tsukamoto)

3. $\mathrm{n}=$ Jumlah data

Sehingga tingkat kesalahan aplikasi penentuan jumlah produksi menggunakan metode Fuzzy Tsukamato ini adalah :

$$
\begin{aligned}
\text { MAPE } & =\frac{\sum \frac{\mathrm{x}_{1}-\mathrm{x}_{2}}{\mathrm{x}_{1}} \times 100 \%}{\mathrm{n}} \\
\mathrm{MAPE} & =\frac{\frac{443}{4705} \times 100 \%}{29} \\
\mathrm{MAPE} & =\frac{0.094155 \times 100 \%}{29} \\
\text { MAPE } & =\frac{9.4155 \%}{29} \\
\text { MAPE } & =0.324673 \%
\end{aligned}
$$

Jadi tingkat kesalahan aplikasi penentuan jumlah produksi menggunakan metode Fuzzy Tsukamoto ini adalah $0.324673 \%$, dihitung menggunakan metode Mean Absolute Percentage Error (MAPE).

\section{KESIMPULAN DAN SARAN}

\section{Kesimpulan}

Berdasarkan hasil penelitian mengenai Aplikasi Penentuan Jumlah Produksi Pakaian Di Farhan Konfeksi Kotamobagu Dengan Menggunakan Metode Fuzzy Tsukamoto maka dapat disimpulkan:

1. Berdasarkan pada perhitungan tingkat kesalahan menggunakan metode MAPE, tingkat kesalahan aplikasi penentuan jumlah produksi pada Farhan Konfeksi menggunakan metode Fuzzy Tsukamoto ini adalah $0.324673 \%$.

2. Perbandingan dilakukan antara jumlah produksi oleh Farhan Konfeksi dan berdasarkan hasil perhitungan menggunakan metode fuzzy Tsukamoto ditemukan selisih antara keduanya. Hal tersebut menjadi penyebab terjadinya masalah penumpukan stok pakaian dan kekurangan stok pakaian di Farhan Konfeksi Kotamobagu sehingga dengan adanya aplikasi ini, diharapkan masalah tersebut dapat teratasi dengan lebih efektif dan efisien. 


\section{Saran}

Permasalahan yang diambil pada penerapan metode Fuzzy Tsukamoto untuk menentukan jumlah produksi ini masih sangat sederhana. Masih terdapat beberapa cara yang bisa digunakan untuk membuat aplikasi penentuan jumlah produksi untuk menentukan jumlah produksi yang lebih baik. Metode yang juga bisa digunakan oleh para peneliti selanjutnya guna meningkatkan kinerja aplikasi terkait, antara lain berupa:

1. Menambahkan input berupa faktor lain yang mempengaruhi jumlah pakaian yang akan diproduksi, misalnya jumlah pekerja dan biaya produksi.

2. Menambahkan inferensi fuzzy, sehingga hasil jumlah produksi yang diperoleh semakin akurat.

\section{DAFTAR PUSTAKA}

[1] Kusumadewi, S. dan Purnomo, H, Aplikasi Logika Fuzzy Untuk Sistem Pendukung Keputusan Edisi Pertama, Graha Ilmu, Yogyakarta, 2004

[2] Kusumadewi, S. dan Hartati, S, Neuro-Fuzzy Integrasi Sistem Fuzzy dan Jaringan Saraf. Graha Ilmu, Yogyakarta, 2004

[3] Turban, E., Rainer, R. dan Poter, Introduction to Information Technology (Pengantar Teknologi Informasi), Salemba Infotek, Jakarta, 2006

[4] Klir, G.J., Clair, Ute, S. dan Yuan, Bo, Fuzzy Set Theory, Foundation and Aplication, Prentice Hall International, New Jersey, 1997.

[5] Jang, J.S.R., Sun, C.T. dan Mizutani, E, Neuro-Fuzzy and Soft Computing, Prentice Hall, London, 1997.

[6] Lin, C.T., Lee, C.T. dan George, G.S. 1996. Neural Fuzzy System. Prentice Hall, London, 1996.

[7] Nguyen, Hung, T. dan Elbert, A, W, A First Course In Fuzzy and Neural Control, Chapman \& Hall/CRC, USA, 2005

[8] Setiadji, Himpunan \& Logika Samar serta Aplikasinya, Graha Ilmu, Yogyakarta, 2009

[9] Nasution, A.H, Perencanaan \& Pengendalian Produksi. Graha Ilmu, Yogyakarta, 2008

[10] Moleong, L.J, Metode Penelitian Kualitatif, Remaja Rosdakarya, Bandung, 2002

Michel Farrel Tomatala was born in Ambon on April 7, 1986. He obtained his bachelor degree from Universitas Klabat where he took Information Technology as his major and graduated in May 2008. He then completed his master degree in Universitas Gadjah Madah in 2015 by taking Computer Science as his major. He is categorized senior programmer in North Sulawesi and has managed to create a program for governments such as Taman Nasional Bogani, etc. He is currently teaching at STMIK Multicom Bolaang-Mongondow which is located in Kotamobagu, North Sulawesi and also served as the Head Department of Information Technology Department. His research interest focuses on Artificial Intelligence, Fuzzy, and Microcontroller. 